\title{
Towards an Approach to Ethics and HCI Development Based on Løgstrup's Ideas
}

\author{
Sandra Burri Gram-Hansen \\ Department of Communication and Psychology, Aalborg University, Denmark \\ burri@hum.aau.dk
}

\begin{abstract}
Concurrent with interactive technologies playing an increasingly large part of the lives of people all over the world, ethical reflections concerning the use of such technology are becoming more and more important. Most often ethical evaluations of a technology are based on either a utilitarian or a deontological approach. Both kinds of approaches to the ethics of information technology appear to be inadequate. This paper suggests an alternative based on the works of the Danish philosopher K.E. Løgstrup (1905-1981). On this basis it is argued that an attitude change is required amongst the developers of interactive technologies in order for new technologies to be developed in a truly ethical manner.
\end{abstract}

Keywords: Persuasive design, Ethics, Løgstrup.

\section{Why Ethical Reflections Are Needed}

Computers have become increasingly more pervasive over the years, and a technological approach is being taken to more and more areas where we would previously only have had solutions involving little or no technology. The motivation for this development is an attempt to ease the workload and increase the efficiency of the user by enabling technology to assist with great and small everyday tasks, thus allowing the user to concentrate on other things. However, the complexity of the modern technological society has given rise to a number of ethical considerations. For instance, in most cases the responsibilities for the changes in everyday life could previously be placed upon particular individuals, whereas the responsibility now has to be shared with a large number of rather anonymous developers of various technological devices - and who is then to blame when the new conditions turn out to be inadequate?

Amongst the areas of HCI technologies which in my opinion require special attention, is the field of persuasive design also known as captology. Persuasive design can be defined as a technological design which has an endogenous intent to change a person's behavior or attitude, without using coercion or deception [1]. This definition of captology is undoubtedly meant to clarify that the development theories presented within the field are meant to be applied when creating persuasive technologies which blatantly improve the user's quality of life in some way (for instance. health or educative benefits), without inflicting any negative consequences on the user or anyone else. Nonetheless, the definition is problematic as ethicality of any use of a product is dependent on the perspective of the evaluator. What might be considered ethically 
sound to one person may be entirely unethical from the perspective of others. Ethics can, in other words, be considered a grey area, and it is the existence of such grey areas - in consideration of the increasing pervasiveness of HCI technology - which makes ethical reflections essential to the development process.

Similar to many other HCI fields, the ethical aspects of captology have been approached from a highly utilitarian perspective, which may not be entirely sufficient. Reflecting over possible consequences of using a technology or a design is without doubt important when trying to determine ethicality. It does however seem slightly inadequate to evaluate a technology solely on what may or may not be a possible consequence of its use, as designers and developers are not necessarily able to foresee every possible use of a technology whilst creating it. For instance, the developers of the Nintendo Wii console might not have predicted that the controller could also be used for making an interactive whiteboard ${ }^{1}$.

For the field of captology, the utilitarian approach appears particularly scarce as the endogenous intention of the technology is the core of the design and should as a result be the main focus of an ethical evaluation, despite possible consequences of its use. Instead of referring to utilitarianism one might make use of the deontological perspective according to which ethics should be based on reason and idea that the notion of a good action is based on general principles and rules rather that an analysis of its consequence [2]. However, as we shall see in the following, K.E. Løgstrup was able to present rather strong arguments against this way of seeing the ethical demand of human life.

\section{Introducing Løgstrup's Approach to Ethics}

K.E. Løgstrup presented his approach to ethics as based on the so-called ontological tradition. According to this tradition humans are influenced by basic conditions which are inalterable. For instance, that the lives of humans are inevitably entangled with other humans from the very moment we are born, and that any type of interaction between humans results in a relation of ethical significance. Thereby, the third tradition distances itself from the previous two, by rejecting the possibility of evaluating ethics objectively (based on either actions or the consequences of such), and emphasising that ethics must be considered intuitive and open to be influenced by all humans.

Løgstrup argues that humans are born with several characteristic features such as benevolence, compassion, trust, love and open speech, and that these qualities are essential for the interaction between human beings. Caring for other humans is simply part of human nature, or as he calls it, the ethical demand. The spontaneous manifestations of life can as such be considered the features within human nature which are generally viewed as ethical, contrary to characteristics such as jealousy, hate, mistrust and injustice.

"The demand, precisely because it is unspoken, is radical. This is true even though the thing to be done in any particular situation may be very insignificant. Why is this? Because the person confronted by the unspoken demand must him or herself determine how he or she is to take care of the other person's life."

(Løgstrup 1997, 44)

\footnotetext{
${ }^{1}$ http://www.breakitdownblog.com/interactive-white-board-with-a-nintendo-wii/
} 
The ethical demand in itself is silent; in the way that Løgstrup does not attempt to set up rules concerning ethical and unethical actions. Contrarily, Løgstrup argues that the assessment of the ethicality of actions taken in a given situation must be made by the individual performing the action, in accordance with the reality perception of that individual. Humans must be conscious that any type of human interaction results in a situation where one human becomes responsible for the life of another human being and in accordance with such acknowledgement; humans must strive towards doing to others as they trust others to do to them [3].

Taken into the perspective of technology development, every individual developer needs to be aware of the ethical responsibility which exists whenever a technology is designed and developed. Not only must a given design abide by possible general ethical restrictions and guidelines, but the developer must strive to create a product that will have impact on the user in a way which the developer himself accepts as ethically acceptable. The developer himself should respond to the ethical demand. The ethical evaluation should not be left to a rather distant utilitarian calculation or to an analysis based on rather abstract and general principles.

By defining ethics as an intuitive result of human nature, rather than moral rule based on reason, Løgstrup opposes one of the most recognized philosophers of deontological ethics; Immanuel Kant, who is known especially for introducing the categorical imperative which promotes the idea that ethics, is a matter of acting rationally. Løgstrup makes the argument that ethics based on the human ability to think freely, is problematic as this ability also enables the human mind to justify an action which at first hand does not appear ethical at all. Løgstrup states that humans in general have a clear sense of what is right and what is wrong, but that they also tend to end up in situations where conflict arises between the ethical choice and obligations bound in for instance legislation or profession. In such situations, humans tend to excuse acting against their ethical duty to an extent where the excuses themselves end up appearing as committing as the original ethical duty. The result is a balance between the ethical and the obligated action, which allows the human to choose freely between the two, and thus acting against the ethical duty [4].

\section{Including Ethics in the Development Process}

As mentioned previously, captology is currently defined as focused solely on technologies which are not manipulative or coercive - hence implying that persuasive technologies must be ethically acceptable. Although it seems clear that guidelines and universal codes of ethics are insufficient, the definition of persuasive technology does to a large extent make perfect sense in relation to Løgstrup's viewpoint on ethics. It seems perfectly applicable to define a persuasive technology as being a technology with an endogenous persuasive intention which can be related to the spontaneous manifestations of life, thus making it even more interesting to draw a connection between Løgstrup's perspective on ethics, and modern HCI technology development.

With the main point of Løgstrup's theory being that ethics is intuitive and personal rather than something based on calculations or abstract general principles, one essential aspect of ensuring an ethical approach to technology design must be to ensure that the developers are constantly aware of their individual ethical responsibility. Ethical 
reflections need to be an integrated element of the entire design process, rather than looked upon as an additional consideration once a technology has been put to use. In order to do so, ethical reflections must distinguish between intention in design and the use of technology, as the usage more often deviates from the original intention - a point which has been elaborated upon in more detail by Anders Albrechtslund in his perspective on ethics in a value sensitive design context [5].

As argued by Løgstrup, people are inevitably ontologically connected through their actions, and through the development of HCI technologies, developers become connected and as such responsible for the users via the technologies they produce. In acknowledgement of the impact modern technology has on people worldwide, such responsibility ought not to be taken lightly, but the handling of the responsibility is entirely dependent on the ethical awareness of the individual developer.

Undoubtedly, the commonly taken utilitarian approach to ethically evaluating HCI technologies requires supplement by a more nuanced perspective. In addition to attempting to create guidelines and rules concerning the development and use of HCI devices $^{2}$, developers and researchers should aim to place ethical reflections as a central focus area within any design process. Acknowledgement of the ethical considerations enables the developers to include them within their own range of the process, thus making it more likely that the technologies they design will evoke an ethically acceptable usage.

\section{References}

1. Fogg, B.: Persuasive Technology - Using Computers to Change What We Think and Do. Morgan Kaufmann Publishers, San Francisco (2003)

2. Andersen, S.: Som dig selv - En indføring i etik, Aarhus Universitetsforlag (2003)

3. Løgstrup, K.E.: The Ethical Demand. University of Notre Dame Press (1997)

4. Muckadell, C.S.d.: Løgstrups etik. København, Nordisk Forlag - Gyldendal (1997)

5. Albrechtslund, A.: Ethics and Technology Design. Ethics and Information Technology 9 , 63-72 (2007)

\footnotetext{
${ }^{2}$ For instance the ACM code of ethics - http://www.acm.org/about/code-of-ethics
} 